\title{
Aspecto da pintura de Sidney Amaral
}

\section{Claudinei Roberto da Silva ${ }^{1}$}

1 Artista visual e curador formado em Educação Artística pelo Departamento de Arte da Universidade de São Paulo. Em 2011 foi bolsista do "International Visitor Leadership Program" (Departamento de Estado do Governo dos EUA). Em 2004 atuou como educador no MAC USP; em 2007 foi subcoordenador do Educativo da Fundação Bienal (27 Baenal de São Paulo); em 2009-2010 foi vice-coordenador e coordenador interino dos Núcleos de Educação do Museu da Imagem e do Som de São Paulo/Paço das Artes SP; entre 2010-2013 foi coordenador de Educação no Museu Afro Brasil; 2013-2014, Coordenador Artístico-Pedagógico do projeto "A Journey through African Diaspora", do American Aliance of Museums/ Museu Afro Brasil/ Prince George African American Museum. Experiências em curadoria de exposições recentes: 2016, co-curador da "13a edição da Bienal Naïfs do Brasil" Sesc Piracicaba São Paulo; 2017-2020, "PretAtitude. Insurgências, emergências e afirmações na arte contemporânea afro brasileira" para as unidades do Sesc Ribeirão Preto, São Carlos, Vila Mariana, Santos e São José do Rio Preto. Textos críticos publicados nos catálogos das exposições: "Territórios: Arte Afro-Brasileira no Acervo da Pinacoteca do Estado de São Paulo", 2016 e "Histórias AfroAtlânticas - Antologia 2", MASP, 2018, entre outros. Tem seu trabalho artístico comentado nos catálogos das exposições "A Mão Afro-Brasileira-Significado da contribuição Artística e Histórica 2010 e a Nova Mão Afro Brasileira 2014" Museu Afro Brasil e Imprensa Oficial do Estado de São Paulo. 
Dada a prolixidade da produção pictórica de Sidney Amaral preferi escrever não sobre a totalidade de sua pintura, mas de um aspecto dela. Poderíamos supor que o artista considerava duas questões como fundantes ao pensamento do pintor que ele também era, são eles a Luz e a Sombra. A "luz" pode ser melhor observada no trabalho que ele realiza usando o papel como suporte, o branco desse papel é parte da luz que ele procura extrair das cores que emprega. Este é um pensamento muito próprio àqueles que trabalham com a aquarela, e "aguadas" em geral, segundo os praticantes dessas técnicas dada a transparência das tintas é o branco do papel que "ilumina" as cores. Já a "Sombra" que também é empregada na construção das cores, favorece delas a sua solidez, e possibilita também o modelado das figuras criando ilusões de tridimensionalidade e perspectiva, ou pelo contrário negam essas ilusões quando contornam as figuras confinando-as a um plano. Penso que talvez seja interessante considerar que o artista era também um estudioso e devotado pesquisador da história da arte no ocidente e que no seu trabalho os resultados dessa pesquisa também estão presentes de maneira mais ou menos explicita.

Apesar da sua qualidade, originalidade e importância à arte colonial brasileira são menos conhecidas do que deveriam, podemos afirmar que entre nós o interesse por ela insinua-se na primeira metade do século XX, devido aos esforços de um punhado de intelectuais e artistas, entre eles o fundamental Mário de Andrade, e ao ambiente nacional-populista característico da era Vargas.

Uma das dificuldades que o estudo das realizações artísticas desse período impõe ao pesquisador é a relativa escassez de documentos que confirme suas autorias. Suspeitamos que a mão afro-brasileira estivesse grandemente engajada nessas realizações o que também dificulta o estudo sobre procedência e genealogia desses artefatos já que documentos relativos a esse contingente negro da população são pouco comuns e parte deles foi deliberadamente destruída. Tudo isso contribui para que o acervo do museu de Arte Sacra da cidade de São Paulo seja dos menos conhecidos pelos moradores da cidade em que ele esta sediado. Entre as joias do seu acervo estão três inestimáveis obras do mestiço Antonio Francisco Lisboa, o Aleijadinho principal artista do barroco brasileiro, e dentre elas a mais interessante é uma magnífica Nossa Senhora das Dores realizada pelo mestre mineiro em madeira policromada no século XVIII. Quando potentes as obras de arte tem a faculdade de manterem-se senão atuais, pelo menos interessantes através das relações que estabelecem com o público, desse modo podemos apreendê-las observando-as em perspectiva a partir da nossa experiência contemporânea. Para além do simbolismo de caráter sacro e devocional aquela Nossa Senhora das Dores é a representação da dor incomensurável da mãe do mártir, a obra traz a partir do talho do Aleijadinho a dor de um tempo onde vigorava a violência da escravidão. Seria possível estabelecer uma relação entre essa obra e aquelas que na contemporaneidade buscam traduzir o infinito de dor do povo negro e periférico. Seria razoável buscar um sentido outro na "Das Dores" do Aleijadinho além daquele que ela mais obviamente expressa? Um sentido que justificasse classifica-la como obra senão de "protesto" a maneira de algumas daquelas realizadas por Sidney Amaral, pelo menos de solidariedade 
ao povo sofrido das senzalas? Afinal Antonio Francisco Lisboa participou daquela sociedade e conhecia seus horrores, observar o que é interno e o que é externo a obra, o que é intrínseco e o que é extrínseco significa considerar o que nela esta representa suas qualidades formais, constitutivas, estruturais, materiais e objetivas e aquelas que compõe seu conteúdo, assunto, evocação. A contemporaneidade em Sidney Amaral também estava expressa na maneira como ele incorporava na sua obra, notadamente na fração dela dedicada a pintura elementos que estão presentes na obra de artistas do passado e não apenas como citação, apropriação ou mera gag visual. Observando sua obra pictórica concluímos sem esforço que Sidney Amaral tinha pleno domínio dos meios que elegeu para exprimir suas impressões sobre a arte e o mundo, e na sua pintura onde o emprego da tinta acrílica, a óleo e a aquarela são empregados com a mesma acuidade, o autorretrato era recorrente, essa insistência na autorrepresentação nos informa sobre a necessidade de reescrever a historia da arte no Brasil a partir dessa referência enegrecida. Ou antes, o artista concluiu que nas galerias e nos salões reservados a exibição desse gênero de pintura o rosto negro aparece, quando aparece, quase sempre como objeto de interesse ou motivo pitoresco do artista branco. $O$ mencionado apuro técnico, tão peculiar às obras de Amaral foi sendo paulatinamente conquistado através da prática continuada de exercícios a que ele se submetia, são inúmeros os cadernos que foram preenchidos com seus desenhos da figura humana e estudos sobre cor, esse exercício ás vezes refutado por graduandos nas escolas de arte era metodicamente realizado pelo artista antes da execução de uma obra, e os resultados desse esforço podem ser conferidos no acervo de algumas das mais prestigiadas instituições culturais brasileiras.

Nos seus autorretratos o artista geralmente aparece em situações que confirmam que o homem ali retratado num drama qualquer representa muito mais que o próprio artista, seu rosto e seu corpo é claro, um símbolo, não existe intenção de apresentar uma biografia, um enredo pessoal de uma intransferível, pelo contrario, sua mascara pertence a todos negros e negras que a partir dela encontram uma voz. Numa série importante de pinturas uma vez mais vemos o artista representado em situações diversas e o que de comum existe nessa série é o fundo completamente preto onde esta personagem atual. É assim na tela algo metafísica "O enigma entre eu e tu", e na violenta denuncia contida na pintura "Mãe Preta (a fúria de lansã) ambas de 2014". O fundo preto também comparece em trabalhos realizados com aquarela, nanquim e lápis como "Bem me quer, mal me quer" de 2014 e em "Como construir cidades" de 2012, nesse trabalhos é possível aventar o interesse do artista pela escola Barroca e Maneirista, seu interesse pelo italiano Michelangelo Merisi, dito Caravaggio (15711610) e o espanhol Francisco de Zurbaram (1598-1664) e o "tenebrismo", os artistas mencionados não raramente faziam suas personagens emergir de um cenário de treva absoluta, sempre envolto por sombras e sendo teatral e dramaticamente iluminados, existe no caso da "Mãe preta" certo parentesco com as "degolações" pintadas pela também italiana Artemisia Gentileschi (1593-1652) no século XVII, Gentileschi realizou pinturas de grande impacto com o tema Judith degolando Holofernes, em pelo menos uma delas o sangue jorra abundantemente do pescoço da vítima enquanto o decapitação é realizada. Como sabemos, a pintora italiana foi vitima de um estupro 
nas dependências do ateliê de seu pai, e foi a Justiça buscando reparação e punição ao violador e venceu a causa, pinturas como essa parecem buscar simbolicamente justiça feminista contra um ambiente de opressão masculina, a personagem da artista praticou a violência para livrar seu povo de um tirano. De todo modo tanto em Gentileschi da "Judith" quanto em Amaral da "Mãe Preta" é a rebelião contra a injustiça que levam aos extremos representados nas telas.

Disso depreende o fato de estarmos diante de um artista de produção densa, complexa e profícua, que procurou no dialogo nas variadas fontes de informação/ formação os subsídios que robustecem seu trabalho pinçando na história da arte do ocidente referências que às vezes utilizadas para acusar este mesmo ocidente das barbáries promovidas contra negras e negros, indígenas e todos os que divergem de um ideal do capitalismo predatório heteronormativo branco e excludente.

https://pt.wikipedia.org/wiki/Judite_decapitando_Holofernes

https://artrianon.com/2017/10/02/obra-de-arte-da-semana-judite-e-holofernes-de-caravaggio/

https://artebrasileiros.com.br/arte/artigo/sidney-amaral-entre-a-afirmacao-e-a-imolacao/ 